\title{
The role of bacterial symbionts in the biodegradation of chlorpyrifos in the digestive tract of Plutella xylostella larvae
}

\author{
MOCHAMMAD SYAMSUL HADI ${ }^{1, \boldsymbol{}}$, ABDUL LATIEF ABADI ${ }^{1}$, TOTO HIMAWAN ${ }^{1}$, \\ MASRURI $^{2}$, SAFIRA RIZKA LESTARI ${ }^{1}$, BAMBANG TRI RAHARDJO ${ }^{1}$, LUQMAN QURATA AINI ${ }^{1}$, \\ YOGO SETIAWAN ${ }^{1}$, HAGUS TARNO ${ }^{1}$ \\ ${ }^{1}$ Department of Plant Pests and Diseases, Faculty of Agriculture, Universitas Brawijaya. Jl. Veteran, Malang 65145, East Java, Indonesia. \\ Tel.: +62-341-569237, `email: msh@ub.ac.id \\ ${ }^{2}$ Department of Chemistry, Faculty of Mathematics and Natural Sciences, Universitas Brawijaya. J1. Veteran, Malang 65145, East Java, Indonesia
}

Manuscript received: 13 October 2020. Revision accepted: 12 January 2021.

\begin{abstract}
Hadi MS, Abadi AL, Himawan T, MAsruri, Lestari SR, Rahardjo BT, Aini LQ, Setiawan Y, Tarno H. 2021. The role of bacterial symbionts in the biodegradation of chlorpyrifos in the digestive tract of Plutella xylostella larvae. Biodiversitas 22: $702-712$. Several species in the order Lepidoptera act as plant pests, one of which is Plutella xylostella. Plutella xylostella is one of the most destructive pests of cabbage and other horticultural crops. The use of chemical insecticides as pest control for P. xylostella causes many problems, such as the increased pest resistance to pesticides. The objectives of this study are: (i) to obtain and characterize symbiont bacteria in the digestive tract of $P$. xylostella collected from organic and conventional agriculture soils; (ii) to evaluate the potential of bacterial symbionts in the digestive tract of $P$. xylostella from organic and conventional soils in degrading the active ingredient of chlorpyrifos insecticide; (iii) To determine the biodegradation process of chlorpyrifos insecticide by symbiont bacteria in the digestive tract of P. xylostella; and (iv) to identify the derivative compounds from the biodegradation of chlorpyrifos insecticide. The results showed 30 symbiont bacteria isolated from the digestive tract of $P$. xylostella collected from organic soil and 36 symbiont bacteria isolated from the digestive tract of $P$. xylostella from conventional farming soil. There are 15 species of symbiont bacteria in 5 genera from the digestive tract of $P$. xylostella from organic and conventional farming capable of degrading the chlorpyrifos insecticide. They are identified as Providencia sp., Pseudomonas sp., Serratia sp., Proteus sp., and Aeromonas sp. Chlorpyrifos-derived compounds from the biodegradation of symbiont bacteria are less toxic than chlorpyrifos compounds.
\end{abstract}

Keywords: Biodegradation, chlorpyrifos, digestive insect, Plutella xylostella, symbiont bacteria

\section{INTRODUCTION}

Insects are the largest group of organisms on earth (Kalshoven 1981). Several species in the order Lepidoptera are known as plant pests. Plutella xylostella (Lepidoptera: Yponomeutidae) is one of the most destructive cabbage pests and other horticultural crops (Shakeel et al. 2017). Plutella xylostella is a cosmopolitan pest that is found mostly in tropical areas in Indonesia. The damage caused by this caterpillar is very typical, i.e., leaves with transparent holes and visible leaf veins (Kalshoven 1981). The damage and production loss caused by $P$. xylostella can be prevented by chemical insecticide application. In Indonesia, The most common chemical insecticides to control these pests in Indonesia are the Organophosphate, Pyrethroid, and Carbamate groups (Prabaningrum et al. 2016).

Chlorpyrifos (0.0-diethyl 0-3,5,6-trichloro-2-pyridyl phosphorothioate) with the molecular formula of $\mathrm{C}_{9} \mathrm{H}_{11} \mathrm{Cl}_{3} \mathrm{NO}_{3} \mathrm{PS}$ is one of the active ingredients of pesticides in the organophosphate group. Chlorpyrifos is a broad-spectrum non-systemic insecticide and termiticide; it acts as an acetylcholinesterase inhibitor (George et al. 2014). The insecticide chlorpyrifos has a half-life of 34 to 46 days (Singh et al. 2004). It can survive in the soil for 60 to 120 days and has a low water solubility of $2 \mathrm{mgL}^{-1}$
(Ardiwinata et al. 2020). The insecticide chlorpyrifos is widely used for controlling $P$. xylostella (Ghaima et al. 2020). However, chemical insecticide application causes many problems, such as increased pest resistance to pesticides, environmental pollution, death of non-target animals, and toxic chemical residues in the soil (Tong et al. 2013; Prabaningrum et al. 2016). In particular, pest resistance to insecticides has currently become a serious problem. Krieger (2010) reported that further examination of the pest mechanisms for developing resistance was not widely carried out. The intensive and continuous use of chemical insecticides with the same active ingredient is one of pest resistance causes (Prabaningrum et al. 2016). Li et al. (2017) reported a relationship between symbiont bacteria in the digestive tract of $P$. xylostella and the biodegradation process of insecticides. Several types of bacteria associated with the digestive tract of $P$. xylostella can degrade several insecticidal active ingredients that act as gastrin toxins, especially from the organophosphate group (Moekasan et al. 2004; Xia et al. 2013; Li et al. 2017). This symbiont is a community of bacteria that live in association with other biotas (hosts) and carry out various types of relationship patterns according to the essential characteristics of their interactions (Kim et al. 2015). The specific interaction between the symbiont and the host is related to the digestive tract, so that it can reduce 
the chlorpyrifos insecticide into a compound molecule with a different structure from chlorpyrifos. These derivative molecules can be inactive and non-toxic, but they can also be more toxic to P. xylostella pests than chlorpyrifos (Xia et al. 2013; Li et al. 2017).

The diversity of symbiont bacteria in the digestive tract of pests, especially $P$. xylostella, affects $P$. xylostella to degrade the chlorpyrifos insecticide. Symbiont bacteria usually utilize carbon groups from active insecticidal compounds to degrade the active compounds for cell metabolism (Wilkinson 1976). Xu et al. (2008) reported that the main product of chlorpyrifos degradation is 3,5,6trichloro-2-pyridinol (TCP), which will break down further into organic acid compounds and carbon dioxide. This study aimed to (i) obtain and characterize symbiont bacteria in the digestive tract of $P$. xylostella collected from organic and conventional agriculture soils; (ii) evaluate the potential of bacterial symbionts in the digestive tract of $P$. xylostella in degrading the active ingredient of chlorpyrifos insecticide; (iii) evaluate the biodegradation process of chlorpyrifos insecticide by symbiont bacteria in the digestive tract of $P$. xylostella; and (iv) determine the mechanism of biodegradation process of the derivatives of the chlorpyrifos insecticide

\section{MATERIALS AND METHODS}

\section{Collection of Plutella xylostella larvae}

Larvae collection was carried out in the organic farming village in Brenjonk, Trawas Sub-District, Mojokerto Regency, and conventional farming in Junrejo Village, City of Batu. Chlorpyrifos insecticide was applied every 2 days in Junrejo Village, City of Batu. Farmers routinely and intensively apply chlorpyrifos pesticide once a week to control P. xylostella in Junrejo Village, City of Batu. Fifty larvae of $P$. xylostella were collected from each location and taken to the laboratory to dissect the digestive tract and isolate the symbiont bacteria.

\section{Exploration, isolation, and purification of symbiont bacteria}

Larvae collected from each location were sterilized by immersing in $70 \%$ ethanol for 60 seconds, followed by immersion in $5 \% \mathrm{NaOCl}$ solution for 60 seconds, and rinsed with sterile distilled water. Furthermore, $P$. xylostella larvae were dissected, and a part of their digestive tract was taken. The digestive tract of $P$. xylostella was taken by the aseptic technique with microtweezers and macro-tweezers to hold the body. The surgery was performed on fourth instar larvae without hitting the thorax (head). The digestive tract was then collected into microtubes.

The digestive tract of $P$. xylostella was dissolved in distilled water and homogenized with a vortex. The homogeneous suspension was diluted by pouring $1 \mathrm{ml}$ of the suspension into $9 \mathrm{ml}$ of distilled water. It was repeated 10 times in dilutions. One hundred $\mu \mathrm{l}$ of the dilution was cultured on NA media by spread plate method using a glass Drigalski spatula before being incubated for 48 hours.
Bacteria grew on NA media were separated based on shape, color, edge, elevation, and other morphological characteristics, and re-culture on new NA media for purification.

\section{Bioassay of symbiont bacteria using in vitro method}

Purified bacteria were selected for their ability to degrade the active ingredient of chlorpyrifos. The selection process uses the methods of Kim et al. (2015). Bacterial isolates originating from the digestive tract aged 24 hours were diluted in distilled water to $10^{9} \mathrm{CFU} / \mathrm{ml}$. These bacteria were cultured on NA growth media. In the treatments where clear zones were present, the bacterial isolates were selected for further testing. The presence of clear zones indicates that the bacteria can degrade the active ingredient of the chlorpyrifos insecticide. The wider clear zones produced by bacteria after 48 hours of incubation indicate their potential to degrade the chlorpyrifos insecticide. The ability to degrade the chlorpyrifos insecticide by symbiont bacteria by dissolving the phosphate groups in the chlorpyrifos compound. It is indicated by the formation of a clear zone around the colony (Singh et al. 2004).

\section{Physiological and morphological characterization}

A physiological test was carried out to determine the nature, characteristics, and bacterial resistance under certain conditions. A physiological test includes a Gram test, fermentative oxidative test, YDC (Yeast Dextrose Agar) test, King's B, air mycelium, and hypersensitivity test on tobacco plants. Bacterial morphology was carried out to identify the tested bacteria based on cell shape and colony. Physiological characterization followed the Laboratory Guidelines by Schaad et al. (2001).

\section{Molecular characterization}

Bacteria were selected for their ability to degrade the active ingredients of cypermethrin, chlorpyrifos, and methomyl insecticides. Identification of selected bacterial isolates was carried out based on the 16S rRNA gene sequence. The sequencing process of the $16 \mathrm{~S}$ rRNA gene involved DNA extraction, amplification of the 16S rRNA gene with PCR (Polymerase Chain Reaction), PCR-generated electrophoresis, and sequencing (Duraisamy et al. 2018).

\section{Analysis of insecticide residue}

Insecticide residues in culture media were analyzed according to Ebrahimpour et al. (2012). It was performed with Liquid Chromatography-Mass Spectrometry (LCMS/MS). One $\mathrm{ml}$ of the bacterial suspension was taken and put into nutrient broth (NB) media mixed with chlorpyrifos insecticide (1000 ppm), and then incubated for 48 hours. 10 $\mathrm{ml}$ of the suspension was taken and centrifuged to obtain the supernatant. The supernatant was washed with $1 \mathrm{ml}$ of chloroform and extracted by the maceration method for $1 \mathrm{x}$ 24 hours. The active compound was separated from the supernatant with $1 \mathrm{ml}$ of $\mathrm{n}$-hexane produced a clear filtrate. The filtrate was evaporated with a rotary vacuum evaporator at $45-50{ }^{\circ} \mathrm{C}$ at a speed of $65-90 \mathrm{rpm}$. One $\mathrm{ml}$ of 
extract was taken and analyzed using Liquid Chromatography-Mass Spectrometry (LC-MS/MS).

\section{Toxicity assessment of biodegradation compounds from chlorpyrifos insecticide}

Chemical compounds resulted from the biodegradation process of chlorpyrifos insecticide residues were tested for their toxicity against $P$. xylostella. It was performed by the sandwich method by observing the mortality rate of $P$. xylostella larvae. The number of $P$. xylostella larvae used for the test was ten larvae per replication. The sandwich method refers to the research by Wiyantono and Minarni (2009) as follows: two pieces of $4 \times 4 \mathrm{~cm}^{2}$ cabbage leaves in which one piece of the leaves was smeared with a solution of biodegradation compound, and to the other piece of leaves was applied with $2 \%$ Agristick adhesive. Both pieces of the leaves and ten larvae of $P$. xylostella were stacked together in a Petri dish. Observations were carried out at $6,12,24,48$, and 72 hours after incubation. The number of larvae that died was recorded every day until the pupal stage. It was repeated 3 times for each sample in each treatment.

\section{Data analysis}

The mortality rate of larvae from the toxicity assessment was analyzed with ANOVA, followed by DNMRT testing with a level of $5 \%$. All the data were analyzed through the Microsoft Excel program.

\section{RESULTS AND DISCUSSION}

\section{Morphological and physiological characterization of symbiont bacteria from the digestive tract of Plutella xylostella}

There are 66 isolates of symbiont bacteria collected from the digestive tract of. P. xylostella. Thirty isolates of symbiont bacteria were isolated from the digestive tract of P. xylostella from organic farming, and 36 isolates from those of conventional farming. They were morphologically different based on the shape and color of the colonies
(Table 1). Physiological characterization was carried out on all symbiont bacteria isolates and the results were presented in Table 2.

\section{Selection of the ability of symbiont bacteria in the digestive tract of Plutella xylostella to degrade chlorpyrifos residue}

The results showed that the ability of symbiont bacteria from the digestive tract of $P$. xylostella to degrade chlorpyrifos was varied. The degradation ability is indicated by the formation of a clear zone around the bacterial colony in growth media containing the active ingredient chlorpyrifos.

The average clear zone diameter produced by symbiont bacteria from organic farming was $1.46 \mathrm{~cm}$. The highest clear zone diameter was obtained from the symbiont bacteria MSH_O9 $(1.76 \mathrm{~cm})$, while the lowest clear zone diameter was obtained from the symbiont bacteria MSH_O6 (1.20 cm) (Table 3). Ten symbiont bacteria are isolated from conventional farming that can degrade chlorpyrifos, namely MSH_K1, MSH_K2, MSH_K9, MSH_K12, MSH_K14, MSH_K15, MSH_K23, MSH_K25, MSH_K26, and MSH_K27 isolates (Table 4). The symbiont bacteria from conventional farming had an average diameter of clear zone of $1.65 \mathrm{~cm}$. The symbiont bacteria isolate MSH_K12 had the highest diameter of 2.40 $\mathrm{cm}$, while the bacterial symbiont isolates MSH_K2 and MSH_K26 had the lowest diameter $(1.40 \mathrm{~cm})$ (Table 4).

\section{Molecular characterization of selected symbiont bacteria isolates}

Molecular characterization was carried out on fifteen isolates of symbiont bacteria with high potential in degrading chlorpyrifos insecticide. It was performed by the Polymerase Chain Reaction (PCR) method. PCR amplification was performed with $16 \mathrm{~S}$ rRNA primers. The amplified DNA was then separated by agarose gel electrophoresis and visualized with UV light. The visualization results of agarose gel electrophoresis of 15 bacterial symbiont isolates were presented in Figure 1.

Table 1. Morphological characteristics of symbiont bacteria in the digestive tract of Plutella xylostella from organic and conventional farming

\begin{tabular}{|c|c|c|c|c|}
\hline Shape & Color & Surface & Edge & No. of isolates \\
\hline Rounded & Yellowish white & Convex & Wavy & 8 \\
\hline Rounded & White & Convex & Wavy & 2 \\
\hline Rounded & Yellowish white & Convex & Equal & 13 \\
\hline Rounded & Yellow & Convex & Equal & 7 \\
\hline Rounded & White & Convex & Equal & 3 \\
\hline Rounded & Pink & Convex & Equal & 1 \\
\hline Oval & Yellowish white & Convex & Wavy & 4 \\
\hline Oval & Yellow & Convex & Equal & 2 \\
\hline Oval & Yellowish white & Convex & Equal & 5 \\
\hline Oval & White & Convex & Equal & 2 \\
\hline Irregular & Yellowish white & Convex & Wavy & 6 \\
\hline Irregular & White & Convex & Wavy & 2 \\
\hline Irregular & Yellowish white & Convex & Equal & 5 \\
\hline Total & & & & 66 \\
\hline
\end{tabular}


Table 2. Physiological characterization of symbiont bacteria in the digestive tract of Plutella xylostella

\begin{tabular}{|c|c|c|c|c|c|c|c|}
\hline Genus & Gram & OF & YDC & KB Ed & $\mathbf{A M}$ & Isolate code & $\begin{array}{c}\text { No. of } \\
\text { isolates }\end{array}$ \\
\hline Corynebacterium & + & $\mathrm{F}$ & & - & & $\begin{array}{l}\text { MSH_K3, MSH_K4, MSH_K7, MSH_K8, MSH_K11, MSH_K13, } \\
\text { MSH_K16, MSH_O2, MSH_O3, MSH_O4, MSH_O5, MSH_O8, } \\
\text { MSH_O11, MSH_O13, MSH_O14, MSH_O15, MSH_O16, MSH_O17, } \\
\text { MSH_O18, MSH_O19, MSH_O20, MSH_O21, MSH_O22, MSH_O23, } \\
\text { MSH_O24, MSH_O25, MSH_O26, MSH_O27, MSH_O28, MSH_O29, } \\
\text { MSH_O30 }\end{array}$ & 31 \\
\hline Clostridium & + & $\mathrm{F}$ & & + & & MSH_K6, MSH_K17, MSH_K18, MSH_K19, MSH_K20 & 5 \\
\hline Bacillus & + & $\mathrm{O}$ & & + & & MSH_K10 & 1 \\
\hline Xanthomonas & - & $\mathrm{O}$ & + & - & & MSH_K21, MSH_K22 & 2 \\
\hline Pantoea & - & $\mathrm{F}$ & + & & & MSH_K24, MSH_K28, MSH_K29, MSH_K31, MSH_K32, MSH_K36 & 6 \\
\hline Pseudomonas & - & $\mathrm{O}$ & + & + & & MSH_K1, MSH_K9, MSH_K23, MSH_K30 & 4 \\
\hline Erwinia & - & $\mathrm{F}$ & - & & & MSH_K33, MSH_K34, MSH_K35 & 3 \\
\hline Streptomyces & + & & & - & + & MSH_O7, MSH_O10, MSH_O12 & 3 \\
\hline Uncultured 1 & + & $\mathrm{F}$ & & - & & MSH_K2, MSH_K12, MSH_K14, MSH_K15, MSH_O1, MSH_O9 & 6 \\
\hline Uncultured 2 & - & $\mathrm{O}$ & + & + & & MSH_K25, MSH_K26, MSH_K27 & 3 \\
\hline Uncultured 3 & + & & & - & + & MSH_O6 & 1 \\
\hline
\end{tabular}

Note: $\mathrm{OF}=$ Oxidative/Fermentative; YDC = Yeast Dextrose $\mathrm{CaCO}_{3} ; \mathrm{KB}=$ King's B; Ed = Endospore; AM = Air Mycelium; MSH_O = organic land; $\mathrm{MSH} \_\mathrm{K}=$ conventional land

The results of the 16s rRNA gene amplification by polymerase chain reaction (PCR) and separation with agarose gel electrophoresis showed that the DNA total bases were from 6000 to $8000 \mathrm{bp}$. The DNA visualization results were amplified in the PCR process and then sequenced to determine the nucleotide sequence of the detected DNA fragments. The DNA sequencing results were analyzed by the BLASTN (nucleotide blast) program to determine the suitability of the nucleotide base sequences from $16 \mathrm{~S}$ rRNA sequencing with data from the Genbank of the National Center for Biotechnology Information (NCBI) on the website http://www.ncbi.nlm.nih.gov. The sequencing analysis of symbiont bacteria from the soil of organic farming is presented in Table 5.

The data from the DNA sequencing of symbiont bacteria from the soil of organic farming showed that the symbiont bacteria isolate with the code MSH_O10 had the highest homology (100\%) against the SML Pseudomonas aeruginosa strain. In contrast, the MSH_O9 isolate had the lowest homology (90.89\%) against uncultured Providencia sp. clone ORM_056L.

The DNA visualization of symbiont bacteria from the soil of conventional farming was amplified by PCR and analyzed by the BLASTN program is presented in Table 6.

\section{Biodegradation of the chlorpyrifos insecticide by symbionts bacteria from the digestive tract of Plutella xylostella}

The results showed that the ability to degrade chlorpyrifos insecticide of the symbiont bacteria from organic farming soil was $19.89 \%$ on average (Table 7 ). The highest degradation ability was obtained from the symbiont bacteria MSH_O6 which was homologous to Serratia nematodiphila strain UMAGOD14. Bacteria MSH_06 can reduce the chlorpyrifos insecticide up to $33.48 \%$. The lowest degradation ability $(0.49 \%)$ was obtained from the symbiont bacteria MSH_O9. This symbiont bacteria was homologous to uncultured Providencia sp. ORM_056L clone (Table 7).

Table 3. The diameter of clear zones for organic soil

\begin{tabular}{llc}
\hline Isolate code & Genus & Clear zone diameter $(\mathbf{c m})$ \\
\hline MSH_O1 & Uncultured 2 & 1.48 \\
MSH_O9 & Uncultured 2 & 1.76 \\
MSH_O10 & Uncultured 1 & 1.34 \\
MSH_O12 & Uncultured 1 & 1.50 \\
MSH_O6 & Uncultured 3 & 1.20 \\
Average & & 1.46 \\
\hline
\end{tabular}

Table 4. The diameter of clear zones for conventional land

\begin{tabular}{llc}
\hline Isolate code & Genus & Clear zone diameter $(\mathbf{c m})$ \\
\hline MSH_K1 & Pseudomonas & 1.48 \\
MSH_K2 & Uncultured 1 & 1.40 \\
MSH_K9 & Pseudomonas & 1.76 \\
MSH_K12 & Uncultured 2 & 2.40 \\
MSH_K14 & Uncultured 1 & 1.67 \\
MSH_K15 & Uncultured 2 & 1.50 \\
MSH_K23 & Pseudomonas & 1.76 \\
MSH_K25 & Uncultured 2 & 1.43 \\
MSH_K26 & Uncultured 2 & 1.40 \\
MSH_K27 & Uncultured 2 & 1.67 \\
Average & & 1.65 \\
\hline
\end{tabular}




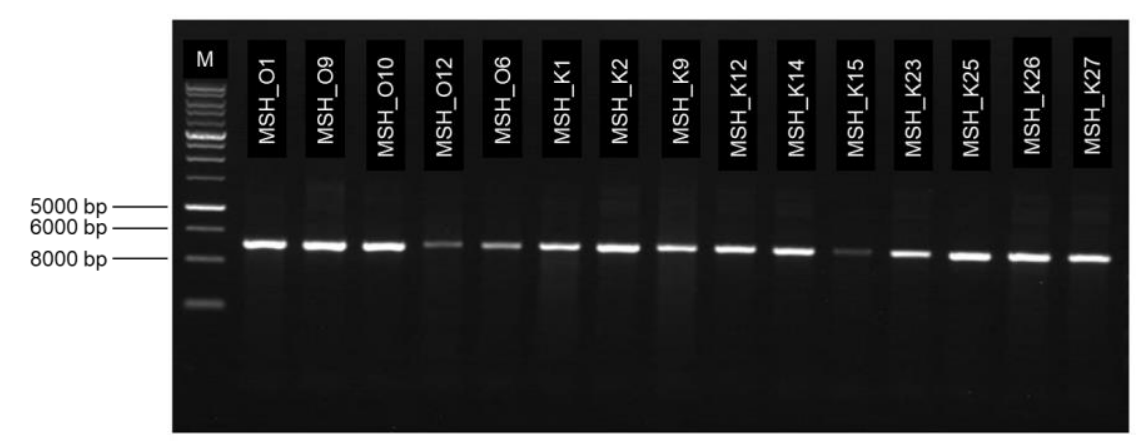

Figure 1. Visualization of agarose gel electrophoresis amplified the $16 \mathrm{~S}$ rRNA gene of 15 selected symbiont bacteria. M = DNA Ladder $10,000 \mathrm{bp}$.

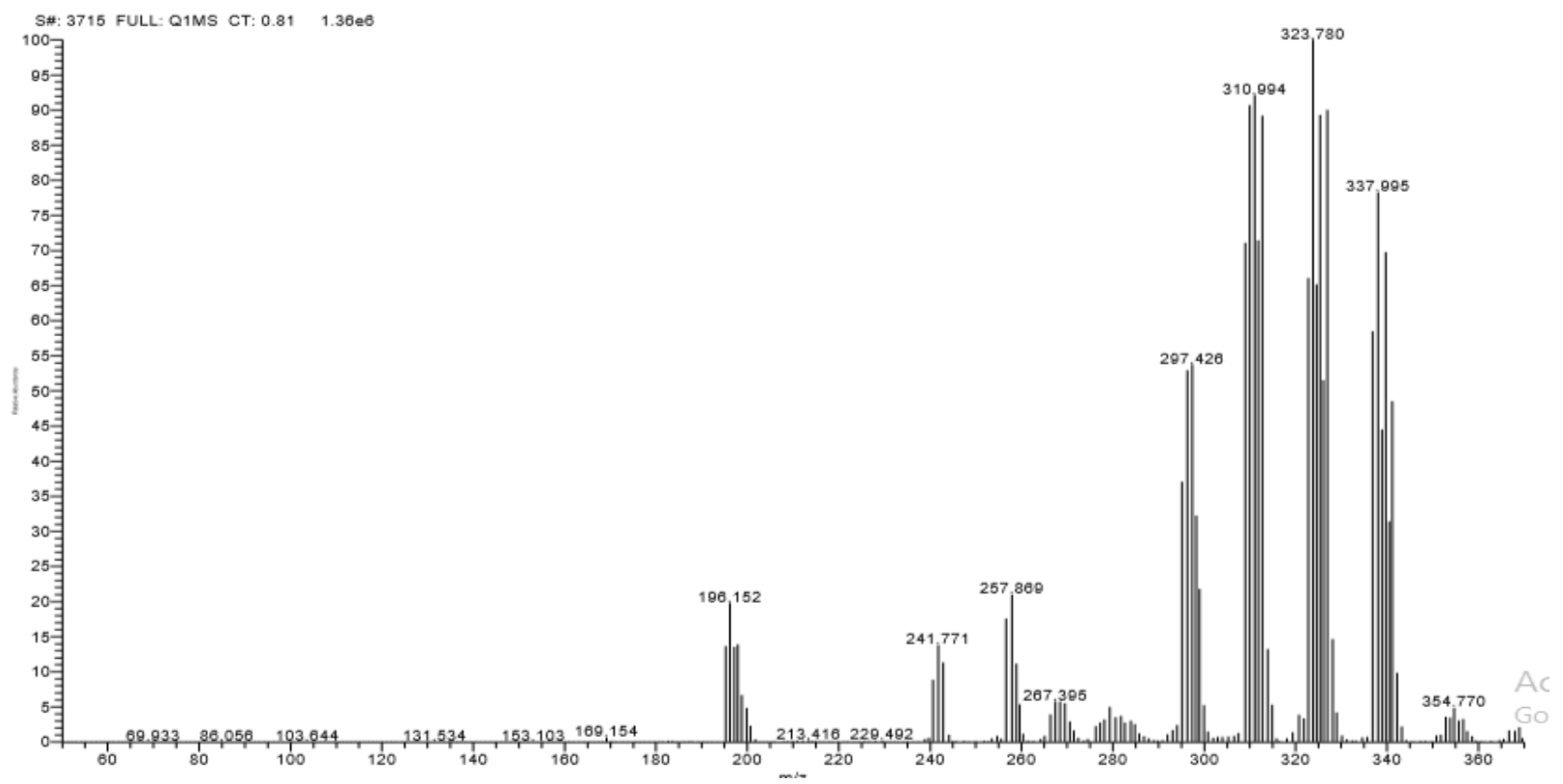

Figure 2. Chromatogram of chlorpyrifos derivative compound at $30 \mathrm{~V}$

Analysis of biodegradation ability was also carried out on selected symbiont bacteria from conventional farming soil. On average, the selected bacteria from conventional farming soil could degrade the chlorpyrifos insecticide by $21.92 \%$. (Table 8). The highest degradation ability $(40.27 \%)$ was obtained from the symbiont bacteria MSH_K12; it was homologous to Providencia vermicola strain 176 . The lowest degradation ability was the symbiont bacteria MSH_K26, which could reduce chlorpyrifos by $7,50 \%$ (Table 8). It was homologous to Providencia rettgeri strain $\mathrm{L} 1$.

\section{Identification of compounds derived from the biodegradation process of chlorpyrifos insecticides}

The results of LC-MS/MS analysis of derived compounds from the biodegradation process of chlorpyrifos by symbiont bacteria showed nine derivative compounds with molecular masses of 196, 241, 257, 267, 197, 310, 323, and $337 \mathrm{~m} / \mathrm{z}$ (Figure 2). It also showed several changes in the chemical structure of the chlorpyrifos insecticide (Figure 2).
The biodegradation process of chlorpyrifos produced ten derivatives compounds with differences in the chemical structure compared to the structure of chlorpyrifos. The first derivative compound comes from dealkylation process of the organophosphorus group, produced a derivative compound O-(3,6-dichloro-5-hydroxypyridin-2-yl) O,Odiethyl phosphorothioate with a molecular mass of 330 $\mathrm{m} / \mathrm{z}$; chlorine $(\mathrm{Cl})$ in the chlorpyrifos compound was replaced by a hydroxide $(\mathrm{OH})$. The second derivative compound was O-(3,6-dichloropyridin-2-yl) O,O-diethyl phosphorothioate with a molecular mass of $314 \mathrm{~m} / \mathrm{z}$; the chlorine $(\mathrm{Cl})$ compound on the side chain is missing. The third derivative compound was O-(3-chloro-5,6dihydroxypyridin-2-yl) O,O-diethyl phosphorothioate with a molecular mass of $312 \mathrm{~m} / \mathrm{z}$; two chlorine $(\mathrm{Cl})$ groups were replaced by hydroxide $(\mathrm{OH})$ groups. The fourth derivative compound was O,O-diethyl O-(3,5,6trihydroxypyridin-2-yl) phosphorothioate with a molecular mass of $295 \mathrm{~m} / \mathrm{z}$; three chlorine $(\mathrm{Cl})$ groups on the side chain were replaced by hydroxide $(\mathrm{OH})$ groups. 
Table 5. Sequencing analysis of selected symbiont bacterial isolates from the soil of organic farming

\begin{tabular}{llll}
\hline Isolate code & BLASTN results (NCBI database) & Query cover & Homology \\
\hline MSH_O1 & Serratia marcescens strain NPKC3_2_1 & $99 \%$ & $99.49 \%$ \\
MSH_O9 & Uncultured Providencia sp. clone ORM_056L & $75 \%$ & $90.89 \%$ \\
MSH_O10 & Pseudomonas aeruginosa strain SML & $100 \%$ & $\mathbf{1 0 0 \%}$ \\
MSH_O12 & Pseudomonas aeruginosa strain DEJ16 & $95 \%$ & $92.02 \%$ \\
MSH_O6 & Serratia nematodiphila strain UMAGOD14 & $100 \%$ & $95.27 \%$ \\
\hline
\end{tabular}

Table 6. Sequencing analysis of selected symbiont bacterial isolates from the soil of conventional farming

\begin{tabular}{llll}
\hline Isolate code & BLASTN results (NCBI database) & Query cover & Homology \\
\hline MSH_K1 & Pseudomonas aeruginosa strain PA-BAT1 & $100 \%$ & $96.81 \%$ \\
MSH_K2 & Providencia vermicola strain ES8027 & $89 \%$ & $95.66 \%$ \\
MSH_K9 & Pseudomonas aeruginosa strain BD0603 & $100 \%$ & $100 \%$ \\
MSH_K12 & Providencia vermicola strain 176 & $99 \%$ & $97.98 \%$ \\
MSH_K14 & Serratia marcescens strain Sm1 & $99 \%$ & $98.10 \%$ \\
MSH_K15 & Proteus mirabilis strain Pm-S1 & $97 \%$ & $91.92 \%$ \\
MSH_K23 & Pseudomonas aeruginosa strain 2CTGx & $99 \%$ & $88.24 \%$ \\
MSH_K25 & Aeromonas hydrophila strain SB 21 & $75 \%$ & $87.35 \%$ \\
MSH_K26 & Providencia rettgeri strain L1 & $100 \%$ & $97.29 \%$ \\
MSH_K27 & Providencia rettgeri strain B5 & $98 \%$ & $94.04 \%$ \\
\hline
\end{tabular}

Table 7. The ability of symbiont bacteria from organic farming soil to degrade chlorpyrifos insecticide

\begin{tabular}{|c|c|c|c|c|}
\hline $\begin{array}{l}\text { Isolates } \\
\text { code }\end{array}$ & Symbiont bacteria & $\begin{array}{l}\text { Initial conc. } \\
(\mathbf{p p m})\end{array}$ & $\begin{array}{l}\text { Final conc. } \\
\text { (ppm) }\end{array}$ & Reduction conc. $(\%)$ \\
\hline MSH_O1 & Serratia marcescens strain NPKC3_2_1 & 1000 & 740.81 & 25.92 \\
\hline MSH_O9 & Uncultured Providencia sp. clone ORM_056L & 1000 & 995.08 & 0.49 \\
\hline MSH_O10 & Pseudomonas aeruginosa strain SML & 1000 & 731.84 & 26.82 \\
\hline MSH_O12 & Pseudomonas aeruginosa strain DEJ16 & 1000 & 872.61 & 12.74 \\
\hline MSH_O6 & Serratia nematodiphila strain UMAGOD14 & 1000 & 665.17 & 33.48 \\
\hline Mean & & & 801.11 & 19.89 \\
\hline
\end{tabular}

The fifth derivative compound resulted from the loss of three chlorine $(\mathrm{Cl})$ groups on the side chain of chlorpyrifos and produced the compound of O-(3-chloropyridin-2-yl) O,O-diethyl phosphorothioate with a molecular mass of $281 \mathrm{~m} / \mathrm{z}$. The sixth compound was (O,O-diethyl phosphorothioic) (E)-2-hydroxy-N-(hydroxymethyl) acetimidic anhydride with a molecular mass of $257 \mathrm{~m} / \mathrm{z}$, where the chlorpyrifos ring bonds were degraded into hydroxide $(\mathrm{OH})$ bonds. The seventh derivative compound was O,O-diethyl O-pyridin-2-yl phosphorothioate with a molecular mass of $247 \mathrm{~m} / \mathrm{z}$, as the ring bond of chlorpyrifos became lost, leaving the oxygen $(\mathrm{O})$ element.

The next change in the chlorpyrifos insecticide is in the aromatic group. The first change is the change in the aromatic group which produce resulted in a derivative compound O-ethyl O-(3,5,6-trichloropyridin-2-yl) Ohydrogen phosphorothioate with a molecular mass of 322 $\mathrm{m} / \mathrm{z}$, in which the oxygen $(\mathrm{O})$ element replaced by a hydroxide $(\mathrm{OH})$ group. The second change produced a derivative compound O-(3,5,6-trichloropyridin-2-yl) O,Odihydrogen phosphorothioate with a molecular mass of 292 $\mathrm{m} / \mathrm{z}$, in which two oxygen $(\mathrm{O})$ elements replaced by hydroxide $(\mathrm{OH})$ groups. The last change resulted in a derivative compound 3,5,6-trichloropyridin-2-ol with a molecular mass of $196 \mathrm{~m} / \mathrm{z}$, as the aromatic group was missingt from the ring bond of the chlorpyrifos insecticide.

\section{Toxicity assessment of chlorpyrifos insecticide-derived compounds}

The results showed that chlorpyrifos insecticide was more toxic than the derivative compounds produced from biodegradation process by symbiont bacteria. It is indicated by reducing the mortality rate of $P$. xylostella larvae in the treatment of derivative compounds compared to chlorpyrifos compounds. Derivative compounds produced by $P$. aeruginosa and Serratia sp. have the lowest mortality rate, Mortality rate of $P$. xylostella larvae treated with derivatives compounds number 3 and 13 was the lowest among other treatments at 24, 48, and 72 hours after application. In general, the chlorpyrifos insecticide-derived compounds produced from the biodegradation process by the symbiont bacteria from $P$. xylostella were less toxic than chlorpyrifos compounds (Table 9). 
Dealkylation of the Organophosphorus Group<smiles>CCOP(=O)(OCC(C)(C)C)Oc1nc(Cl)c(O)cc1Cl</smiles>

hydroxypyridin-2-yl) O,O-diethyl phosphorothioate

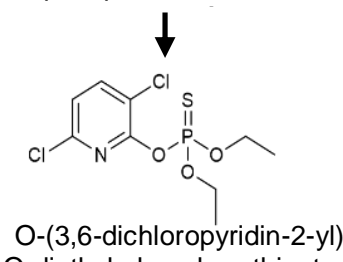

O,O-diethyl phosphorothioate<smiles></smiles>

dihydroxypyridin-2-yl) O,O-diethyl phosphorothioate

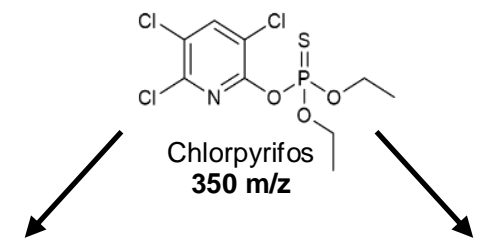

\section{Overhaul of the Aromatic Group}<smiles>CCOP(O)(=S)Oc1nc(Cl)c(Cl)cc1Cl</smiles>

O-ethyl O-(3,5,6-trichloropyridin-2 yl) O-hydrogen phosphorothioate

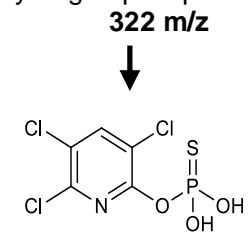

O-(3,5,6-trichloropyridin-2-yl) O,O dihydrogen phosphorothioate<smiles>Oc1cc(CCCCCCOc2ccccc2)c(Cl)c(Cl)n1</smiles>
3,5,6-trichloropyridin-2ol $196 \mathrm{~m} / \mathrm{z}$

trihydroxypyridin-2-yl) phosphorothioate

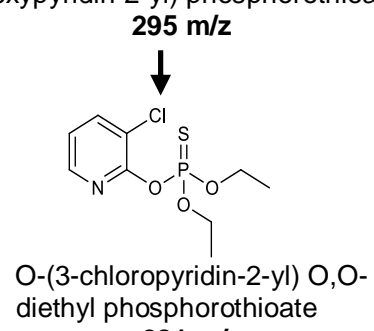

diethyl phosphorothioate

$\downarrow$<smiles>CCOP(=S)(OCC)O/C(CO)=N/CO</smiles>

(O,O-diethyl phosphorothioic) (E)-2hydroxy-N-(hydroxymethyl)acetimidic

$$
\text { anhydride }
$$

$\downarrow$<smiles>CCOP(=S)(OCC)Oc1ccccn1</smiles>

O,O-diethyl O-pyridin-2-yl phosphorothioate

Figure 3. Chlorpyrifos derived compounds from the biodegradation process by symbiont bacteria 
Table 8. The ability of symbiont bacteria from conventional farming soil to degrade chlorpyrifos insecticide

\begin{tabular}{llccc}
\hline Isolates code & Symbiont bacteria & $\begin{array}{c}\text { Initial conc. } \\
\text { (ppm) }\end{array}$ & $\begin{array}{c}\text { Final conc. } \\
\text { (ppm) }\end{array}$ & Reduction conc. (\%) \\
\hline MSH_K1 & Pseudomonas aeruginosa strain PA-BAT1 & 1000 & 677.21 & 32.28 \\
MSH_K2 & Providencia vermicola strain ES8027 & 1000 & 741.45 & 25.86 \\
MSH_K9 & Pseudomonas aeruginosa strain BD0603 & 1000 & 746.86 & 25.31 \\
MSH_K12 & Providencia vermicola strain 176 & 1000 & 597.32 & 40.27 \\
MSH_K14 & Serratia marcescens strain Sm1 & 1000 & 643.62 & 35.64 \\
MSH_K15 & Proteus mirabilis strain Pm-S1 & 1000 & 875.73 & 12.43 \\
MSH_K23 & Pseudomonas aeruginosa strain 2CTGx & 1000 & 846.52 & 15.35 \\
MSH_K25 & Aeromonas hydrophila strain SB 21 & 1000 & 847.18 & 15.28 \\
MSH_K26 & Providencia rettgeri strain L1 & 1000 & 925.00 & 7.50 \\
MSH_K27 & Providencia rettgeri strain B5 & 1000 & 907.65 & 9.24 \\
Mean & & & 780.85 & 21.92 \\
\hline
\end{tabular}

Table 9. The mortality rate of $P$. xylostella larvae treated with chlorpyrifos derivative compounds

\begin{tabular}{|c|c|c|c|}
\hline \multirow{2}{*}{ Derivative compounds } & \multicolumn{3}{|c|}{ Mortality (\%) at incubation period } \\
\hline & 24 hours & 48 hours & 72 hours \\
\hline Pseudomonas aeruginosa strain MSH_K1 & $1.00 \pm 0.10 \mathrm{~cd}$ & $20.00 \pm 0.02 \mathrm{fgh}$ & $46.80 \pm 0.04 \mathrm{bc}$ \\
\hline Providencia vermicola strain MSH_K2 & $1.33 \pm 0.10 \mathrm{c}$ & $33.40 \pm 0.01 \mathrm{defg}$ & $46.20 \pm 0.06 \mathrm{bc}$ \\
\hline Pseudomonas aeruginosa strain MS̄H_K9 & $0.00 \pm 0.13 \mathrm{e}$ & $6.60 \pm 0.03 \mathrm{hi}$ & $26.60 \pm 0.02 \mathrm{de}$ \\
\hline Providencia vermicola strain MSH_K12 & $0.67 \pm 0.16$ cde & $20.20 \pm 0.02 \mathrm{fgh}$ & $46.60 \pm 0.06 \mathrm{bc}$ \\
\hline Serratia marcescens strain MSH_K14 & $0.33 \pm 0.02 \mathrm{de}$ & $13.40 \pm 0.10 \mathrm{ghi}$ & $46.40 \pm 0.06 \mathrm{bc}$ \\
\hline Proteus mirabilis strain MSH_K15 & $1.31 \pm 0.07 \mathrm{c}$ & $40.00 \pm 0.04 \mathrm{cdef}$ & $53.40 \pm 0.10 \mathrm{~b}$ \\
\hline Pseudomonas aeruginosa strain MSH_K23 & $2.71 \pm 0.03 b$ & $60.00 \pm 0.03 \mathrm{bc}$ & $60.20 \pm 0.04 b$ \\
\hline Aeromonas hydrophila strain MSH_25 & $2.72 \pm 0.03 b$ & $66.60 \pm 0.02 b$ & $93.40 \pm 0.02 \mathrm{a}$ \\
\hline Providencia rettgeri strain MSH_K26 & $0.68 \pm 0.06$ cde & $26.20 \pm 0.12 \mathrm{efgh}$ & $45.40 \pm 0.02 \mathrm{bc}$ \\
\hline Providencia rettgeri strain MSH_K27 & $1.02 \pm 0.01 \mathrm{~cd}$ & $25.80 \pm 0.05$ efgh & $53.20 \pm 0.05 \mathrm{~b}$ \\
\hline Serratia marcescens strain MSH_O1 & $0.00 \pm 0.10 \mathrm{e}$ & $13.60 \pm 0.03 \mathrm{ghi}$ & $40.00 \pm 0.04 \mathrm{bc}$ \\
\hline Uncultured Providencia sp. strain MSH_O9 & $1.29 \pm 0.01 \mathrm{c}$ & $53.40 \pm 0.04 \mathrm{bcd}$ & $60.4 \pm 0.06 b$ \\
\hline Pseudomonas aeruginosa strain MSH_O10 & $0.03 \pm 0.01 \mathrm{e}$ & $5.600 \pm 0.03 \mathrm{hi}$ & $6.60 \pm 0.06 \mathrm{de}$ \\
\hline Pseudomonas aeruginosa strain MSH_O12 & $1.01 \pm 0.03 \mathrm{~cd}$ & $42.20 \pm 0.04$ cde & $60.00 \pm 0.06 \mathrm{~b}$ \\
\hline Serratia nematodiphila strain MSH_Ō & $1.28 \pm 0.06 \mathrm{c}$ & $38.00 \pm 0.03 \mathrm{def}$ & $44.20 \pm 0.13 \mathrm{bc}$ \\
\hline Without derivative compounds & $0.00 \pm 0.03 \mathrm{e}$ & $0.00 \pm 0.10 \mathrm{j}$ & $0.00 \pm 0.10 \mathrm{e}$ \\
\hline With chlorpyrifos compounds & $100 \pm 0.10 \mathrm{a}$ & $100.00 \pm 0.10 \mathrm{a}$ & $100.00 \pm 0.10 \mathrm{a}$ \\
\hline
\end{tabular}

\section{Discussion}

The diversity of the genera of symbiont bacteria in the digestive tract of $P$. xylostella collected from the organic and conventional farming soils was affected by the habitat and diet of the host (Colman et al. 2012).

In Brenjonk, yard organic farming using permanent beds with a mixed planting media of soil and compost. Farmers grow cabbage in a screen house known as the Organic Vegetable House. Antagonistic microbes were applied to protect the plant without using synthetic chemicals in organic farming. The influence of the outside ecosystem was easier to be controlled in the screen house; therefore the diet of $P$. xylostella larvae can be controlled. The type of diet affects the diversity of symbiont bacteria in the digestive tract of the host. A study by Visôtto et al. (2009) showed that the diet of velvet bean larvae (Anticarsia gemmatalis) affected the diversity of symbiont bacteria in the digestive tract of $A$. gemmatalis. A more varied diet causes an increase in the diversity of symbiont bacteria in the digestive tract of $A$. gemmatali. However, giving the same diet every day causes a decrease in the symbiont bacteria.

The diversity of symbiont bacteria in conventional farming might be influenced by habitat, dietary, and insecticide application. Cabbage plants on conventional farming are planted on open land. In conventional farming, cabbage is planted in monoculture on one plot and surrounded by different crops such as maize, chilies, and tomatoes on the other plots. Pest control in conventional farming of cabbage is carried out regularly and intensively by chemical insecticides such as chlorpyrifos. So, it allows $P$. xylostella pest to interact more widely with the surrounding environment. Sarfraz et al. (2006) reported that $P$. xylostella also consumes secondary host plants containing glucosinolate compounds. The secondary host plants of $P$. xylostella are plants that are considered as weeds such as Raphanus raphanistrum, Thlaspi arvense, and Nasturtium officinale commonly found in Indonesia 
(Sastrosiswojo and Sastrodihardjo 1986). Several previous studies by Kahuthia-Gathu et al. (2008), Shehzadi et al. (2015), and Paniagua Voirol et al. (2018) showed that the composition and diversity of symbiont bacteria of $P$. xylostella depend on pest preferences and host plants. Host plants could primary host plants such as cabbage and secondary hosts such as Raphanus raphanistrum, Thlaspi arvense, and Nasturtium officinale.

Studies by Indiragandhi et al. (2008) and Ramya et al. (2016) reported that routine application of insecticides increases type, number, and diversity of symbiont bacteria in the digestive tract of $P$. xylostella. These symbiont bacteria are capable of producing enzymes such as carboxylesterase and esterase that degrade the active compounds of insecticide.

Based on the explanation above, the diversity of the symbiont bacteria genera of $P$. xylostella is influenced by the habitat, diet, and intensity of insecticide application. $P$. xylostella in conventional farming has more diversity of host plants than $P$. xylostella in organic farming. The diversity of host plants and also more diverse nutritional intake determines the variation of symbiont bacteria genera in the digestive tract of $P$. xylostella. Another factor that affects the diversity of symbiont bacteria is the intensive application of insecticides, which increases the diversity of symbiont bacteria (especially symbionts) that can degrade the active ingredients of insecticides.

Symbiont bacteria isolates from organic and conventional soil farming showed different abilities to degrade chlorpyrifos. It showed by varying clear zone diameters. Differences might influence by morphological and physiological characteristics of the symbiont bacteria isolates. Iranzo et al. (2001) and Vischetti et al. (2002) reported that the ability of bacteria to degrade organophosphate pesticides depends on their morphological and physiological characteristics. A study by Akbar and Sultan (2016) showed that specific bacteria could degrade phosphate from a chemical compound by dissolving it. such as the organophosphate pesticide group, especially the chlorpyrifos insecticide.

Gram-negative bacteria were more potential to degrade chlorpyrifos than Gram-positive bacteria. It indicated by wider clear zone formation. Physiological characteristics of Gram-negative bacteria, such as Enterobacter, allow the bacteria to be more effective in degrading pesticides compared to Gram-positive bacteria, especially the chlorpyrifos insecticide (Singh et al. 2004). Zhu et al. (2019) comparing the ability of Bacillus megaterium and Pseudomonas syringae to degrade the chlorpyrifos insecticide, and the results showed that $P$. syringae had a better ability to degrade chlorpyrifos insecticide up to $99 \%$, while $B$. megaterium was able to degrade chlorpyrifos insecticide up to $92 \%$.

Bacteria produced the optimal diameter of the clear zone at 7 to 8 days of incubation is 0.71 to $0.14 \mathrm{~cm}$ on culture media containing 3 to $5 \%$ phosphate. In these conditions, the bacteria can reduce phosphate compounds by 35 to $50 \%$.

The symbiont bacteria obtained in this study were able to dissolve phosphate groups in the chlorpyrifos insecticide. There were 5 symbiont bacteria from organic farming that have an average clear zone of $1.46 \mathrm{~cm}$, and 10 isolates of symbiont bacteria from conventional farming have an average clear zone of $1.65 \mathrm{~cm}$. This shows that the selected symbiont bacteria from the soils of organic and conventional farming can optimally degrade phosphate compounds in the insecticide chlorpyrifos up to $50 \%$.

The data from DNA sequencing of symbiont bacteria isolates from conventional land show that the symbiont bacteria isolate with the code MSH_K9 had the highest homology of $100 \%$ against Pseudomonas aeruginosa strain BD0603. Meanwhile, there were 2 symbiont bacteria isolates with codes MSH_K23, which had $88.24 \%$ homology with Pseudomonas aeruginosa strain 2CTGx, and MSH_O25, which had the lowest homology of $87.35 \%$ with Aeromonas hydrophila strain SB21.

The sequencing results of symbiont bacteria isolates from organic and conventional farming showed different homological percentages. Sequencing DNA samples with a homology level of $100 \%$ indicated that the DNA of the sample has the same structure and function as the comparable DNA (Pearson 2013). The sequencing of 15 symbiont bacteria isolates, showed that 2 isolates of symbiont bacteria from conventional farming had the lowest (MSH_K23 and MSH_K25), with homologous of $88.24 \%$ and $87.35 \%$ respectively. It means that the two isolates of the symbiont bacteria only had the same DNA structure and function by up to 87 to $88 \%$ to the comparable DNA. Further research is needed by analyzing their orthologs and paralogs (Pearson 2013). Orthology is a homology-based on physiological functions that change according to environmental conditions or speciation, and paralogy is a homology-based on genetic duplication (Pearson 2013).

The findings showed that several species of selected symbiont bacteria with different strains possessed the ability to effectively degrade chlorpyrifos insecticide. The symbiont bacteria of Providencia sp., Pseudomonas sp., and Serratia sp. from organic and conventional farming were the Enterobacteriaceae group, which can degrade the active ingredient chlorpyrifos. These results are consistent with the research by Rani et al. (2008) that Providencia sp. has the potential to degrade the chlorpyrifos insecticide. Providencia sp. can grow on culture media and chlorpyrifos-contaminated soil at the concentration of 700 $\mathrm{mg} / \mathrm{L}$ and degrade the chlorpyrifos insecticide up to 50 $\mathrm{mg} / \mathrm{L}$. A study conducted by Sasikala et al. (2012) showed that Pseudomonas sp. can degrade the chlorpyrifos insecticide. Pseudomonas sp. and especially $P$. aeruginosa reduce the concentration of chlorpyrifos concentration by $42 \%$. Ifediegwu et al. (2015) also stated that the reduction in chlorpyrifos concentration by $P$. aeruginosa was $60 \%$. Xia et al. (2013) showed that Serratia sp. could degrade the chlorpyrifos insecticide by 30 to $40 \%$.

Besides those bacterial strains, several types of symbiont bacteria from the digestive tract of $P$. xylostella also can degrade the chlorpyrifos insecticide. Some of these bacteria are the Proteus sp., and Aeromonas sp. John (2014) reported that Proteus sp. can degrade chlorpyrifos up to $150 \mathrm{mg} / \mathrm{L}$ within 120 hours. A study by Hernández et 
al. (2011) showed that Proteus sp. can degrade chlorpyrifos up to $83.60 \%$ within 72 hours of incubation. Besides, a study by Dellai et al. (2016) showed that Aeromonas sp. is a pathogenic bacteria that can degrade chlorpyrifos more than $50 \%$ in the digestive tract of fish. It can be concluded that the symbiont bacteria that have a high potential to degrade or reduce the concentration of the chlorpyrifos insecticide are the Providencia sp., Pseudomonas sp., Serratia sp., Proteus sp., and Aeromonas sp.

The fifteen isolates of symbiont bacteria that had been selected were able to reduce the concentration of chlorpyrifos compounds. Chlorpyrifos compound is a hydrocarbon compound that is used as a poison for insect pests. According to Hernández et al. (2011), there are types of bacteria that are able to utilize hydrocarbon compounds as a source of metabolic energy in their bodies, and these bacteria are called hydrocarbonoclastic bacteria. According to Gray et al. (2013), bacteria that can utilize hydrocarbon compounds have a special responsibility to toxic compounds such as chlorine and phosphate by releasing catalase and peroxidase enzymes. These enzymes are released as a form of detoxification when bacterial cells experience reactive chlorine species (RCS) So, the bacterial metabolism is filled with chlorine compounds. The decrease in chlorpyrifos compounds might be due to the presence of catalase and peroxidase enzymes produced by the 15 selected symbiont bacteria. Catalase and peroxidase enzymes allow the chemical structure of chlorpyrifos to be converted into new and simpler compounds.

The mechanism of symbiont bacteria in degrading chlorpyrifos insecticide is by utilizing carbon compounds as an energy source for cell metabolism. It can be indicated by the biodegradation compounds of the symbiont bacteria,i.e the derivative compounds O-(3,5,6trichloropyridin-2-yl) O,O-dihydrogen phosphorothioate and 3,5,6-trichloropyridin-2-ol. Wilkinson (1976) stated that the main energy source that can be utilized by the symbiont bacteria in the chlorpyrifos insecticide for cell metabolism is hydrocarbon compounds. Besides, symbiont bacteria also have a special mechanism to overcome toxic chlorine compounds by releasing catalase and peroxidase enzymes (Gray et al. 2013)

Catalase and peroxidase enzymes are produced by chlorine poisoned bacteria. The derivatives compound of O-(3,6-dichloro-5-hydroxypyridin-2-yl) O,O-diethyl phosphorothioate; O-(3,6-dichloropyridin-2-yl) O,Odiethyl; O-(3-chloro-5,6-dihydroxypyridin-2-yl) O,Odiethyl phosphorothioate; O,O-diethyl O-(3,5,6trihydroxypyridin-2-yl) phosphorothioate; O-(3chloropyridin-2-yl) O,O-diethyl phosphorothioate; (O,Odiethyl phosphorothioic) (E)-2-hydroxy-N(hydroxymethyl) acetimidic anhydride; and O,O-diethyl Opyridin-2-yl phosphorothioate was produced when the chlorpyrifos was eliminated. This result indicated that the symbiont bacteria in the digestive tract of $P$. xylostella experience RCS. Therefore, they release catalase and peroxidase enzymes to break down the chlorine.

The biodegradation process produced 10 changes in the chlorpyrifos insecticide's chemical structure as derivative compounds. The derivative compound of 3,5,6-
Trichloropyridine is a compound commonly produced from the biodegradation of the chlorpyrifos insecticide (Abraham and Silambarasan 2015).

Compounds of O-(3,6-dichloro-5-hydroxypyridin-2-yl) O,O-diethyl phosphorothioate; O-(3,6-dichloropyridin-2yl) O,O-diethyl; O-(3-chloro-5,6-dihydroxypyridin-2-yl) O,O-diethyl phosphorothioate; O,O-diethyl O- $(3,5,6-$ trihydroxypyridin-2-yl) phosphorothioate; O-(3chloropyridin-2-yl) O,O-diethyl phosphorothioate; (O,Odiethyl phosphorothioic) (E)-2-hydroxy-N(hydroxymethyl) acetimidic anhydride; and O-diethyl Opyridin-2-yl phosphorothioate have never been reported as derivatives of the biodegradation of the chlorpyrifos insecticide. Therefore, these chemical compounds are new compounds produced from the biodegradation of the chlorpyrifos insecticide by symbiont bacteria.

In conclusion, there are 30 symbiont bacteria isolated from the digestive tract of $P$. xylostella from the soil of organic farming and 36 symbiont bacteria from the digestive tract of $P$. xylostella from conventional farming. There are 15 species, in 5 genera of symbiont bacteria from the digestive tract of $P$. xylostella in organic and conventional that are capable of degrading the chlorpyrifos insecticide (Providencia sp., Pseudomonas sp., Serratia sp., Proteus sp., and Aeromonas sp.) Chlorpyrifos-derived compounds from the biodegradation of symbiont bacteria in the digestive tract of $P$. xylostella are less toxic than chlorpyrifos compounds.

\section{ACKNOWLEDGEMENTS}

Thank you to all those who helped with this research, especially the Ministry of Finance of the Republic of Indonesia, to support the research for doctoral studies to its completion.

\section{REFERENCES}

Abraham J, Silambarasan S. 2016. Biodegradation of chlorpyrifos and its hydrolysis product 3, 5, 6-trichloro-2-pyridinol using a novel bacterium Ochrobactrum sp. JAS2: a proposal of its metabolic pathway. Pestic Biochem Physiol 126: 13-21.

Akbar S, Sultan S. 2016. Soil bacteria showing a potential of chlorpyrifos degradation and plant growth enhancement. Braz J Microbiol 47 (3): 563-570. DOI: 10.1016/j.bjm.2016.04.009.

Ardiwinata A, Ginoga L, Sulaeman E, Harsanti E. 2020. Pesticide Residue Monitoring on Agriculture in Indonesia. J Sumberdaya Lahan 12: 133. DOI: 10.21082 jsdl.v12n2.2018.133-144.

Colman D, Toolson E, Takacs-Vesbach C. 2012. Do diet and taxonomy influence insect gut bacteria communities? Mol Ecol 21: 5124-5137. DOI: $10.1111 /$ j.1365-294X.2012.05752.x

Dellai A, Dridi D, Sakouhi A, Robert J, Djelal J. 2016. Cytotoxic effect of chlorpyrifos ethyl and its degradation derivatives by Pseudomonas peli strain isolated from the Oued Hamdoun River (Tunisia). Toxicol Ind Health 32 (4): 707-713. DOI: 10.1177/0748233713506957.

Duraisamy GS, Mishra AK, Kocábek T, Matoušek J. 2018. Activation of polyketide synthase gene promoter in Cannabis sativa by heterologous transcription factors derived from Humulus lupulus. Biol Plant 62 (2): 250-260. DOI: 10.1007/s10535-017-0766-z.

Ebrahimpour B, Yamini Y, Moradi M. 2012. Application of ionic surfactant as a carrier and emulsifier agent for the microextraction of fluoroquinolones. J Pharm Biomed Anal 66: 264-270. DOI: 10.1016/j.jpba.2012.03.028. 
George N, Chauhan P, Sondhi S, Saini S, Puri N. 2014. Biodegradation and analytical methods for detection of organophosphorous pesticide: Chlorpyrifos. Intl J Pure Appl Sci Technol 20: 79-94.

Ghaima K, Rahal NS, Rahal BS, Mohamed MM. 2020. Biodegradation of chlorpyrifos pesticides by Xanthomonas bacteria isolated from agricultural soil in Baghdad. Plant Cell Biotechnol Mol Biol 21 (1-2): $84-90$.

Gray MJ, Wholey WY, Jakob U. 2013. Bacterial responses to reactive chlorine species. Ann Rev Microbiol 67: 141-160. DOI: 10.1146/annurev-micro-102912-142520.

Hernández M, Ojeda M, Martínez-Vázquez J, Villegas-Cornelio, Córdova-Bautista. 2011. Optimal parameters for in vitro development of the hydrocarbonoclastic microorganism Proteus sp. J Soil Sci Plant Nutr 11 (9): 29-43.

Ifediegwu M, Awah N, Mbachu A, Okeke C. 2015. Isolation, growth and identification of chlorpyrifos degrading bacteria from agricultural soil in Anambra State, Nigeria. Univers J Microbiol Res 3: 46-52. DOI: 10.13189/ujmr.2015.030402.

Indiragandhi P, Anandham R, Madhaiyan M, Poonguzhali A, Kim GH 2008. Cultivable bacteria associated with larval gut of prothiofosresistant, prothiofos-susceptible and field-caught populations of diamondback moth, Plutella xylostella and their potential for, antagonism towards entomopathogenic fungi and host insect nutrition J Appl Microbiol 103: 2664-2675. DOI: 10.1111/j.13652672.2007.03506.x.

Iranzo M, Sainz-Pardo I, Boluda R, Sánchez J, Mormeneo S. 2001. The use of microorganisms in environmental remediation. Ann Microbio $51(2): 135-144$

John E. 2014. Chlorpyrifos degradation using bacterial consortium obtained from soil. Int J Environ Eng 1: 91-94.

Kahuthia-Gathu R, Loehr B, Poehling HM. 2008. Development and reproductive potential of diamondback moth Plutella xylostella (Lepidoptera: Plutellidae) on cultivated and wild crucifer species in Kenya. Intl J Trop Insect Sci 28: 19-29. DOI: 10.1017/S1742758408901375.

Kalshoven LGE. 1981. Pest of Crops In Indonesia. PT. Ichtiar Baru, Jakarta. [Indonesian]

Kim JK, Son DW, Kim CH, Cho JH, Marchetti R, 2015. Insect gut symbiont susceptibility to host antimicrobial peptides caused by alteration of the bacterial cell envelope. J Biol Chem 290 (34): 2104221053. DOI: $10.1074 /$ jbc.M115.651158.

Krieger J. 2010. Single vs. multiple sets of resistance exercise for muscle hypertrophy: A meta-analysis. J Strength Cond Res 24: 1150-1159. DOI: $10.1519 /$ JSC.0b013e3181d4d436.

Li W, Jin D, Shi C, Li F. 2017. Midgut bacteria in deltamethrin-resistant, deltamethrin-susceptible, and field-caught populations of Plutella xylostella, and phenomics of the predominant midgut bacterium Enterococcus mundtii. Sci Rep 7. DOI: 10.1038/s41598-017-02138-9.

Moekasan TK, Sastrosiswojo S, Rukmana T, Sutanto H, Purnamasri IS 2004. Status resistensi lima strain Plutella xylostella L. terhadap formulasi fipronil, deltametrin, profenofos, abamektin, dan Bacillus $\begin{array}{lllll}\text { thuringiensis. } & \mathrm{J} & \text { Hortik } & 14 & \text { (2): } \\ \end{array}$ http://ejurnal.litbang.pertanian.go.id/index.php/jhort/article/view/1120 . [Indonesian]

Paniagua Voirol L, Frago E, Kaltenpoth M, HilkerM, Fatouros N. 2018. Bacterial symbionts in Lepidoptera: Their diversity, transmission, and impact on the host. Front Microbiol 9. DOI: 10.3389/fmicb.2018.00556.

Pearson W. 2013. An Introduction to Sequence Similarity ("Homology") Searching. Curr. Protoc. Bioinformatics Chapter 3: Unit3.1. DOI 10.1002/0471250953.bi0301s42.

Prabaningrum L, Uhan T, Nurwahidah U, Karmin K, Hendra A. 2016. Resistensi Plutella xylostella terhadap insektisida yang umum digunakan oleh petani kubis di Sulawesi Selatan. J Hortik 23: 164. DOI: 10.21082/jhort.v23n2.2013.p164-173. [Indonesian]
Ramya SL, Venkatesan T, Srinivasa Murthy K, Jalali SK, Verghese A. 2016. Detection of carboxylesterase and esterase activity in culturable gut bacterial flora isolated from diamondback moth, Plutella xylostella (Linnaeus), from India and its possible role in indoxacarb degradation. Braz J Microbiol 47: 327-336.

Rani M, Lakshmi K, Devi P, Madhuri R, Aruna S. 2008. Isolation and characterization of a chlorpyrifos- degrading bacterium from agricultural soil and its growth response. Afr J Microbiol Res 2: 2631

Sarfraz R, Dosdall LM, Keddie B. 2006. Diamondback moth-host plant interactions: Implications for pest management. Crop Prot. - Crop PROT 25: 625-639. DOI: 10.1016/j.cropro.2005.09.011

Sasikala C, Jiwal S, Rout P, Mohandass R. 2012. Biodegradation of chlorpyrifos by bacterial consortium isolated from agriculture soil. World J Microbiol Biotechnol 28: 1301-1308. DOI: 10.1007/s11274011-0879-z.

Sastrosiswojo S, Sastrodihardjo S. 1986. Status of biological control of diamondback moth by introduction of parasitoid Diadegma eucerophaga in Indonesia. Lembang, West Java. [Indonesian]

Schaad NW, Jones J. 2001. Laboratory Guide for Identification of Plant Pathogenic Bacteria. American Phytopathological Society. St Paul, $\mathrm{MN}$.

Shakeel M, Farooq M, Nasim W, Akram W, Khan FZ. 2017. Environment polluting conventional chemical control compared to an environmentally friendly IPM approach for control of diamondback moth, Plutella xylostella (L.), in China: a review. Environ Sci Pollut Res 24 (17): 14537-14550. DOI: 10.1007/s11356-017-8996-3.

Shehzadi K, Ahmad M, Bodlah I, Gulzar A. 2015. Susceptibility of diamondback moth, Plutella xylostella (Lepidoptera: Plutellidae) to some Euphorbiaceae plant extracts under laboratory conditions. Asian J Agric Biol 2015: 145-149.

Singh B, Walker A, Morgan J, Wright D. 2004. Biodegradation of Chlorpyrifos by Enterobacter Strain B-14 and its use in bioremediation of contaminated soils. Appl Environ Microbiol 70: 4855-4863. DOI: 10.1128/AEM.70.8.4855-4863.2004.

Tong H, Su Q, Zhou X, Bai L. 2013. Field resistance of Spodoptera litura (Lepidoptera: Noctuidae) to organophosphates, pyrethroids, carbamates and four newer chemistry insecticides in Hunan, China. J Pest Sci 86 (3): 599-609.

Vischetti C, Casucci C, Perucci P. 2002. Relationship between changes of soil microbial biomass content and imazamox and benfluralin degradation. Biol Fertil Soils 35: 13-17. DOI: 10.1007/s00374-0010433-5.

Visôtto LE, Oliveira MGA, Guedes RN, Ribon A, Good PI. 2009. Contribution of gut bacteria to digestion and development of the velvet bean caterpillar, Anticarsia gemmatalis. J Insect Physiol 55: 185-191. DOI: 10.1016/j.jinsphys.2008.10.017.

Wilkinson CF. 1976. Insecticide Biochemistry and Physiology. Springer, New York.

Wiyantono, Minarni EW. 2009. Study on potency of liquid smoke against the cabbage head. J Pembangunan Pedesaan 9 (1): 50-56.

Xia X, Zheng D, Zhong H, Qin B, Gurr G. 2013. DNA sequencing reveals the midgut microbiota of Diamondback Moth, Plutella xylostella (L.) and a possible relationship with insecticide resistance. PLoS One 8: e68852. DOI: 10.1371/journal.pone.0068852.

Xu G, Zheng W, li Y, Wang S, Zhang J. 2008. Biodegradation of chlorpyrifos and 3,5,6-trichloro-2-pyridinol by a newly isolated Paracoccus sp. strain TRP. Int Biodeterior Biodegrad 62: 51-56. DOI: 10.1016/j.ibiod.2007.12.001.

Zhu J, Zhao YAN, Ruan H. 2019. Comparative study on the biodegradation of chlorpyrifos-methyl by Bacillus megaterium CMZ19 and Pseudomonas syringae CM-Z6. Anais da Academia Brasileira de Ciências 91(3). 